\title{
STUDIES ON THE RELATION BEFWEEN ARTICVLATION AND FRELUENCY RANGE
}

\author{
By
}

\author{
H. IWASAKI
}

\section{From the Department of Otolaryngology Osaka Medical School (Director: Prof H. Yamazaki)}

The author measured articulation scores for various bands of frequcncy range by varions combination of high and low pass filters in 25 persons with normal hearing and the following conclusions were obtained.

1) The more narrow the widthth og pass band, the more reducek the articulation. However, the rate of reduction is unproportional to the width of pass band. i.e. articulation of words has ap increasing resitance for dividing the words sounds into narrower bands.

2) A pass band of $1.5-0.25 \mathrm{kc}$ is most important for articulation of Japanese words and holds $30 \%$. ol articulation. This fact will be available to design of hearing aids.

3) Reduced articulation due to interband masking by $0.25-0.15 \mathrm{kc}$ band for the other higher bands can be found in composing the diveded bands.

4) Articulatians for the remaining range by elimination of varions width of band are mcasured and show rklatively better scores than those of the corresponding pass bands.

5) The aconstic spectrums of varions words are mehsured through varigns pass bands and are found comprementary in form as comparcd with the sensitivity curve of the ear.

\section{語音明瞭度と周波数域の研 究 \\ 大阪医科大学耳載呕㑨科教空 (主任：山崎春三教授) \\ 岩、崎弘毅}

目次

1. 緒言

2. 測定裝置

3. band pass による明暸陵測定法

4. 測定成綪

a) band pass に上る蕰吾翻の綜合平均明㮩度

b) band pass による語曋別明㹉度

5. 語吾の音圧周波数特性

6. band 內成分のみを除去し band 外の語音成分 を聴取させる方法による明暸䓌

a) 測定装置及び測定法

b）测定成綪

7. 総括並に洘㧡

8. 結 論

\section{1. 緒 言}

語音聴力検查で得られる明瞭度成績に影響する原因性 種々なるものがあり，これらは相互に複雑に重畳し合つ ている・これらの原因には聴取語音の強さ，衈取系の周 波数歪，高周波歪，過渡歪，位相歪，エコ一歪，反響， 外来雑音による masking, 語音表の内容, その与光 方法, 速度, これに対する聴取者の年令, 知識内容, 注 意力，環境，検查に対する書取あるい復唱の熟練之協 力等色々あるが，最も重要な原因は語音の強ざで，次导 は聴取系の周波数昰であろう.

語音検查は specch audiometer の減衰器を加減して 与觉る語音の強さを変え，これに対する德取者の語音明 瞭度を測定する方法が一般的であり，語音の強さが最 重要視されている・しかし聴取させる語音即ら受話器あ 
るいはスビーガーよりの再生語音がある音域に限られて いる場合とか，聴取者の聴力がある音域に限られている 場舍には明瞭度に変化を生ずる・これらは従来の語音検 查では, 語音の強さの变化に対する明瞭度変化の中にパ ラネラネーターとして明瞭には区別されていない。

周波数歪とは，等しい強さを有する檑くなる純音が， 変換器の入力端に次をに与えられた時，これらが変換器 の出力端で不同な強さを生ずるなら゙，この变換器は， 周波数歪 (frequency distortion) を有吉ると定義され る. 従つて語音明瞭度之周波数歪の関係は，与户る語音 の強さが一定ならば, 聴取禾の周波数特性と明瞭度との 関保伯相当するから，この基礎知識は最近発達途上にあ る紏㯖器その他の音望機器の設計にも重要である・

周波数歪と明瞭度の関係は既に Fletcher (1929年) によつて研究されていて，耳科学でも，語音了解に重要 な音域は 500-2000cps の間であると云われているが， これらのデーターは Fletcher その他のアメリカの物理 学者の研究に限られ，医学分野では内外共に基礎的研究 が少ない. 近年になつて fileter を使用し語音儿周波 数歪を与兄て明暸度に変化を起させる研究が行われるよ らになつた・吉田及び武山（1954 年），大沢，梅垣及び 加藤 (1956 年)，高橋及び藤代 (1959 年)，柏戸文び殷 蠓 (1959年)である・吉田及び武山は bang pass filter 使用しているが，その他は low pass filter 及び high pass filter を夫ょ単独に使用して Fletcher と同椂な 方法で明膫度の測定を行つている・Fletcher のデータ 一を詳細に検討する如く與味ある現象が認められる・こ れを追求する外に語音了解に必要な音域を测定し白本語 の明瞭度よりその音㗽構造と，耳の感度，周波数特別の 関保を求めるため, low pass 及大び high pass filter を 組合せて種くなる広さの band pass filterを構成させ て明瞭度を测定すると共に，これらの band の語音エ ネルギーを測定した・更にこのデーターを補足するため 飞, band pass とは逆に, その band 内の語音ェネル ギーのみを除去して; 残りの音域を通過させた場合の語 音の眀膯度を測定し興味ある成績を得たので発表する。

\section{2. 測定装置}

デープレコーダー，フイルター，2 回路堌幅器，2個 の受話器よりなる・本奏験で最も重要な filter とは, コイルとニンデンサーの組合せによつて通過させたい band の周佊数の振幅に比して，通過させない周波数の 桭幅を1/1000以下に減少させるものである・第 1 図の a は low pass filter で b は high pass filter $の$ 搆造
を示している・

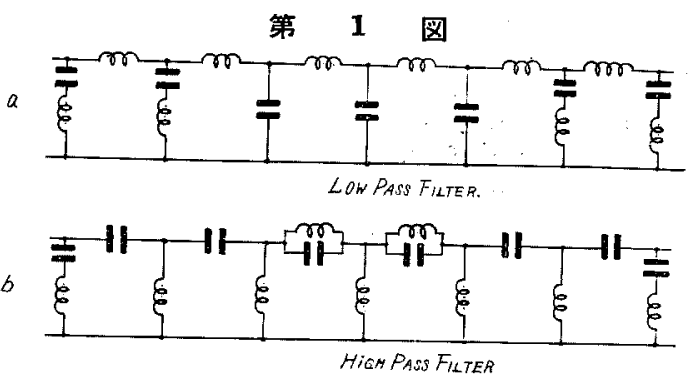

使用した low pass filter の限界周波数は 4.2, 3.0, $2.1,1.5,1.0,0.7,0.5,0.25,0.15 \mathrm{KC}$ であり，例えば L.1.OKC とは， $1000 \mathrm{cps}$ 以下の周波数を通過させ，こ れ上上の周波数はその亦ルギーを $60 \mathrm{db}$ 娍衰させるす のである・

使用した high pass filter の限界周波数は 4.0, 2.5, $1.5,1.0,0.6,0.4,0.25,0.15 \mathrm{KC}$ であり，例えば H.1.0KC とは，1000 cps 以上の周波数を通過させ，これ以下の周 波数は，そのエネルギーを $65 \mathrm{db}$ 減衰させるものであ る.

装置は filter の外に録音テープ (スュッチ制)，テー プレコーダー (東通工製)，減衰器，2回路壇幅器（永 島製)，ダイナミック受話器 (藤木製)よりなつている。 その接続ブロックダイアグラン怔第2図であり，右耳側 の減衰器がいかなる值をとつても, 左耳側の回路の出力 に影箇を及砛ざないよらになつている・

第 2 図（A） band pass に゙る明撙落测定裝置

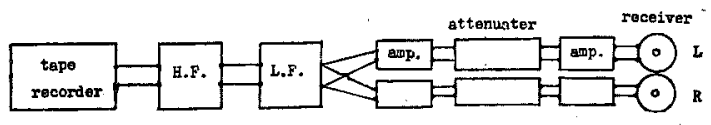

(3) band pass による明瞭度測定法

日本語直音語 67 語について語音の順序のみを変えた 4 種の語音表に従つてろ秒間隔で録音したが，吹込み諸 音は，男声でその強さは v.u.メーターの振れが，標準 目盛に刘して䇴格に $\pm 3 \mathrm{db}$ 以内に達する迄練習を行い， 目的を達し得た録音テープを使用した・な和語音の録音 前に録音の強さに相当する $1000 \mathrm{cps}$ 純音を録音して， これの再生音の強さを基準にして，再年語音の強さを減 衰器で正確に調節できるようにした・敢耳の受話器の再 生純音の強さか间直上 $40 \mathrm{db}$ になるよう夫くの減衰器を 調節 $し て ，$ 第 1 表に示す L 及び H, filter の目盛の組 合せによつて被検者の書取りによる明瞭度を測定した。 
例えば L4.2-H.2.5 の組合せでは，4200〜2500cps の bund 内の語音成分のみが filter を通過して受話器よ り再生される。

第 1 表 high pass $\varepsilon$ low pass filter 組合せを示す

\begin{tabular}{|c|c|c|c|c|c|}
\hline L.H. & L. H. & L.H. & L. H. & L.H. & L. H. \\
\hline $4.2-2.5$ & $3.0-2.5$ & $2.1-1.5$ & $1.5-1.0$ & $1.0-0.6$ & $0.7-0.4$ \\
\hline $4.2-1.5$ & $3.0-1.5$ & $2.1-1.0$ & $1.5-0.6$ & $1.0-0.25$ & $0.7-0.25$ \\
\hline $4.2-1.0$ & $3.0-1.0$ & $2.1-0.6$ & $1.5-0.25$ & $1.0-0.15$ & $0.7-0.15$ \\
\hline $4.2-0.6$ & $3.0-0.6$ & $2.1-0.25$ & $1.5-0.15$ & & \\
\hline $4.2-0.25$ & $3.0-0.25$ & $2.1-0.15$ & & & \\
\hline $4.2-0.15$ & $30-0.15$ & & & & \\
\hline
\end{tabular}

再生語音の強さを閥值上 $40 \mathrm{db}$ の強さとした理由は， filter を使用しない両耳聴では $40 \mathrm{db}$ の強さで最大明膫 度が得られること〉， filter の機能に基いている。 filter の濾波の程度は60db と云われるが，一般に第 2 図の如き周波数特性を有している・故に再生語音の強さ が 60db では band の両隣で約 $15 \mathrm{db}$ の語音成分が聴 取されることになるが，再生語音の強さを $45 \mathrm{db}$ 以下 にするならば，band 以外の周波数成分は完全に除去さ れる。

第 2 図 (B) filter の機能 (Egan and Wiener による)

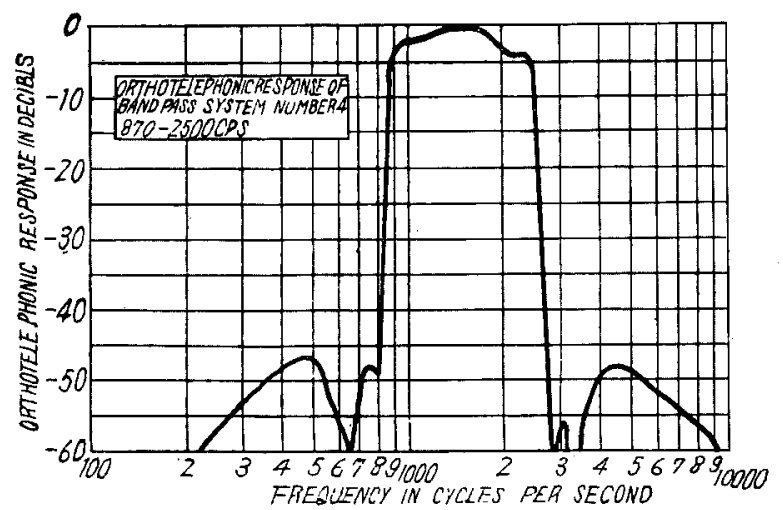

4. 測 定 成樍

a) band pass に上る直音群の綜合平均明瞭度

上記の㮩ヘなる band pass に対する正常聴力者 (20 〜25才） 25 名の明暸度の平均值は第 2 表の如くである。

b) band pass と上る語音別明暸度

直音群の各語音について得られた band pass の明瞭 度は第 3 表の如 く band の上限周波数が 4000 と $3000 \sim$ とでは明腺度
第2表 band pass による值晋群の 明嘹度平均值

\begin{tabular}{|c|c|c|c|c|c|c|}
\hline band k0 & $4.2-2.5$ & $4.2-1.5$ & $4.2-1.0$ & \multirow[t]{2}{*}{$42-0.6$} & \multicolumn{2}{|c|}{$4.2-0.254 .2-0.16$} \\
\hline 明眣度\% & 34.8 & 66.2 & 84.2 & & 94.7 & 94.6 \\
\hline band.KC & $3.0-2.5$ & $3.0-1.5$ & $3.0-1.0$ & $3.0-0.6$ & $3.0-0.25$ & $20-0,16$ \\
\hline 明璄度\% & 33.7 & 66.2 & 81.0 & 88.4 & 97.1 & 97.4 \\
\hline band $k C$ & & $2.1-1.5$ & $2.1-1.0$ & $2.7-0.6$ & $2.7-0.25$ & $2.7-0 / 5$ \\
\hline 明瞈度\% & & 49.7 & 63.4 & 79.3 & 85.7 & 86.7 \\
\hline & & & & & & \\
\hline band $K C$ & & & $1.5-1.0$ & $7.5-0.6$ & $1.5-0.2$ & $1.5-0.15$ \\
\hline 明瞭度\% & & & $5 \% 1$ & 66.8 & 80 & 65.6 \\
\hline & & & & & & \\
\hline band $K C$ & & & & $1.0-06$ & $1.0-0.25$ & $1.0-0.15$ \\
\hline 明睤度\% & & & & 49.5 & 59.7 & 53.5 \\
\hline & & & & & & \\
\hline band $x$ c & & & & $0.7-0.4$ & $0.7-0.25$ & $0.7-0.15$ \\
\hline 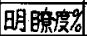 & & & & 38.7 & 47.4 & 44.8 \\
\hline & & & & & & \\
\hline and $K C$ & & & & & $0.5-0.25$ & $0,5-0,16$ \\
\hline 画渎度参 & & & & & 26.7 & 25.3 \\
\hline
\end{tabular}

に殆んど差がないので，前省の成櫝は省略している・高 音の配列は 語音の表のそれと異なり，50 音図の䐓序下 従い小区劃内は明膫度である・

\section{5. 語音の音王周波数特性}

前記の測定焠置をそのま入使用し, その受話器 1 箇下 100〜 4000cps まで殆んど平坦な特性を有する䭽音 計のマイクロホンを気密に接続し，且つ受話器とマ ィク膜の間愫では，約 6cc の空気容積を持たせた。 前記の録音テープより前記の通り種々なる bandを 通じて受話器に生じた語音の強さを騒音計の指糊の 振れで読取り，各 band の音圧值を周波数の順序 に図示すれば，各語音についての音響スペクトルが 得られる・これらのデーターを前記第 2 表及ひ第3

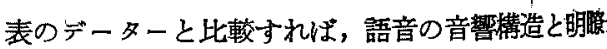
度の関係が求められる。

band pass より測定された直音群の綜合平均 ペクトルは第 3 図である・band 每の音代值は, そ $の$ band 中央の周波数の縦軸で表わしている. 実 線は各 band の平均值を結んだものであり，実楾の上 下の割線は，最大值と最小值を夫々連結したものであ る・同様な測定で得られた stevens, Egan and Miller

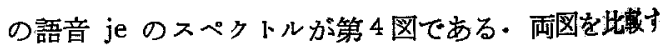
れば je のスペクトルは第3図の割線内にスり得るから 彼等の测定値と著者の測定値とはかなりよく合つている ことが認められる・尤も je は著者の直音群には浑し ないのでここの語音のスペクトルは測定してない 
第 3 表 band pass による語害明膫该

\begin{tabular}{|c|c|c|c|c|c|c|c|c|c|c|c|c|c|c|c|c|c|c|c|}
\hline & & & & & & & & & & & & & & & & & & & \\
\hline & 36 & 64 & 100 & 100 & 100 & 64 & 76 & 100 & 100 & 92 & 92 & 100 & 96 & 100 & 80 & 76 & 84 & 12 & \\
\hline & 48 & 100 & 100 & 100 & 100 & 8 & 68 & 92 & 96 & 28 & 68 & 96 & 76 & 96 & 64 & 88 & & 07 & \\
\hline$j$ & 28 & 76 & 88 & 76 & 100 & 48 & 92 & 80 & 88 & 68 & 42 & 9 & 44 & 100 & 36 & 4 & 24 & & \\
\hline 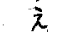 & 60 & 60 & 9 & 100 & 0 & 8 & 60 & 100 & 10 & & 72 & & & 0 & 72 & 68 & 88 & 63 & \\
\hline & 12 & 8 & 8 & 84 & 10 & 8 & 76 & 100 & 80 & 72 & 68 & 100 & 96 & 40 & 72 & 88 & 84 & 20 & 2 \\
\hline & 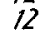 & 80 & 100 & 100 & 100 & 8 & 100 & 100 & 96 & 10 & 100 & 100 & & $n$ & 44 & 56 & & 0 & \\
\hline \pm & 64 & 100 & 80 & 76 & 88 & 8 & 36 & 36 & 36 & 20 & 64 & 6 & 4 & $\eta$ & 40 & 88 & 60 & 52 & 45 \\
\hline$<$ & 0 & 72 & 92 & 96 & 100 & 28 & 100 & 84 & 100 & 80 & 92 & 100 & 100 & 100 & 36 & 52 & 52 & 44 & \\
\hline$H$ & 88 & 96 & 96 & 84 & 100 & 52 & 92 & 52 & 28 & 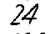 & 56 & 12 & 16 & 12 & 28 & 28 & 20 & 16 & a \\
\hline & & 12 & 100 & 100 & 100 & 24 & 92 & 100 & 100 & 100 & 92 & 96 & 96 & 68 & 96 & 100 & 84 & 16 & 7 \\
\hline & 16 & 76 & 80 & 92 & 92 & 68 & 68 & 60 & 44 & 64 & 64 & 60 & 4 & 16 & 52 & 0 & 12 & 4 & \\
\hline$l$ & 32 & 32 & 76 & 44 & 72 & 36 & 12 & 40 & 56 & 8 & 8 & 44 & 12 & 32 & 8 & 36 & 12 & 24 & \\
\hline 9 & 12 & 172 & 52 & 76 & 72 & 8 & 60 & 64 & 48 & 56 & 36 & 56 & 0 & 0 & 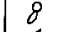 & 8 & 4 & 0 & 4 \\
\hline & 3 & 60 & 56 & 76 & 72 & 0 & 8 & 12 & 32 & 16 & 1 & 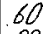 & 0 & & 4 & & & & \\
\hline & 20 & 72 & 84 & 100 & 96 & 48 & 72 & 76 & 76 & 56 & 84 & 88 & 48 & & 16 & 52 & 78 & 0 & $\delta$ \\
\hline$t$ & 12 & 1700 & 100 & 100 & 96 & 4 & 20 & 180 & 80 & 72 & 100 & 80 & 0 & & 40 & 30 & 20 & 4 & \\
\hline$\hbar$ & 8 & 80 & 52 & 50 & 72 & 24 & 12 & 12 & 76 & 20 & 48 & 8 & 16 & 44 & 32 & 36 & 32 & 28 & 20 \\
\hline 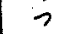 & 2 & 84 & 92 & 88 & 100 & 68 & 80 & 92 & 92 & 56 & 32 & 96 & & 8 & 4 & 20 & & 11 & 12 \\
\hline 2 & 88 & 80 & 96 & 96 & 100 & 68 & 44 & 100 & 96 & 64 & 72 & 80 & 60 & & 52 & 52 & 0 & 56 & 54 \\
\hline$z$ & 2 & 52 & 92 & 96 & 100 & 32 & 76 & 88 & 92 & 68 & 100 & 80 & 7 & & 20 & 36 & 0 & 12 & 12 \\
\hline$t$ & 3 & 100 & 88 & 100 & 100 & 80 & 80 & 100 & 100 & $3 b$ & 96 & 100 & & & 20 & 16 & 32 & 4 & 0 \\
\hline 1 & 64 & 100 & 72 & 100 & 100 & 28 & 36 & 40 & 32 & 48 & 52 & 64 & 0 & 60 & 16 & 52 & 4 & 52 & 20 \\
\hline$\ddot{y}$ & 52 & 56 & 84 & 100 & 100 & 28 & 84 & 88 & 96 & & 44 & 100 & & & 16 & 1 & & 32 & 75 \\
\hline to & 172 & 96 & 96 & 92 & 100 & 36 & 84 & 68 & 64 & & 76 & 64 & & & 48 & 24 & 28 & 28 & 20 \\
\hline (1) & 2 & 48 & 80 & 100 & 100 & 16 & 48 & 100 & 96 & & 00 & 9 & 10 & 100 & 32 & 32 & 19 & 4 & 8 \\
\hline 19 & 20 & 100 & 100 & 96 & 100 & 88 & 100 & 100 & 100 & 100 & 100 & 100 & 92 & 100 & 0 & 60 & & ? & \\
\hline 0 & 60 & 92 & 84 & 84 & 100 & 44 & 32 & 24 & 68 & & 48 & 40 & 20 & 2 & 140 & & 40 & 40 & 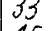 \\
\hline S & 28 & 76 & 92 & 84 & 100 & 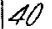 & 84 & 88 & 92 & & 96. & 100 & 76 & 80 & 32 & 56 & 36 & 48 & 15 \\
\hline 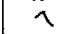 & 6 & 84 & 88 & 92 & $g_{0}$ & 60 & 60 & 92 & 88 & 32 & 68 & 18 & & 76 & 48 & 20 & 44 & 36 & 25 \\
\hline ほ & 20 & 24 & 80 & 88 & 96 & 8 & 64 & 92 & 100 & 80 & 88 & 96 & 80 & 96 & 80 & 9 & 84 & 4 & 16 \\
\hline$\neq$ & 16 & 48 & 160 & 100 & 100 & 36 & 32 & 100 & 100 & 60 & 3 & 96 & 100 & & 2 & & & & \\
\hline 2 & 76 & 100 & 100 & 100 & 1700 & 76 & 84 & 92 & 96 & 52 & 56 & 48 & 20 & 40 & 12 & 28 & 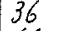 & 14 & 20 \\
\hline ג & $3 c$ & 48 & 88 & 96 & 100 & 32 & 64 & 100 & 100 & 68 & 80 & 96 & 8 & & 36 & 56 & 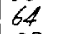 & 20 & 34 \\
\hline$y$ & 5 & 9 & 100 & 100 & 100 & 84 & 80 & 96 & 92 & 92 & 64 & 88 & 2 & & & & 2 & 52 & \\
\hline 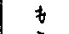 & I & 16 & 80 & 100 & 90 & 1 & 88 & 76 & 100 & 52 & 100 & 10 & 10 & & 92 & 2 & 0 & & $=0$ \\
\hline 5 & 24 & 12 & 76 & 92 & 80 & 16 & 32 & 100 & 72 & 7 & 68 & 100 & 40 & & 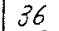 & 9 & & 12 & $A$ \\
\hline$i$ & 8 & 92 & 84 & 100 & 100 & 0 & 48 & 60 & 100 & 0 & 56 & 80 & 44 & & 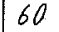 & & & & $7 y$ \\
\hline$z$ & 4 & 96 & 100 & 100 & 100 & 56 & 84 & 96 & & 84 & 6 & 9 & 24 & 16 & 32 & & & 36 & 29 \\
\hline ћ & 2 & 64 & 72 & 100 & 100 & 20 & 6 & 76 & 10 & 41) & 84 & 7 & & & 60 & 48 & & 24 & 66 \\
\hline ろ & 4 & 8 & 96 & 96 & 100 & 64 & 96 & 100 & 16 & 96 & 9 & 9 & & & 64 & 9 & 64 & 44 & 33 \\
\hline は & 0 & 12 & 64 & 20 & 16 & 0 & 56 & 40 & 9 & 3 & 4.4 & 7. & 44 & 56 & 24 & & & 0 & 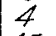 \\
\hline & 28 & 68 & 92 & 92 & 100 & 60 & 40 & 80 & 8 & /t & $\%$ & 60 & 4 & & 36 & & 28 & 4 & \\
\hline S & 8 & 40 & 56 & 72 & 100 & 28 & 56 & 92 & $g_{t}$ & 76 & 2 & 100 & & 95 & 0 & & & 32 & 20 \\
\hline & 8 & 6 & 44 & 76 & 80 & 56 & 2 & 76 & 4 & & 16 & 68 & & 24 & 26 & 16 & & & 16 \\
\hline & 4 & il & 5 & 48 & 48 & 4 & 44 & 48 & 60 & & 4 & 24 & & 4 & 2 & & & & \\
\hline 加 & 0 & 100 & 100 & 100 & 100 & 96 & 100 & 100. & 100 & 8 & 9 & 96 & & 2 & 4 & & & & 12 \\
\hline & i & 7 & 5 & 80 & 100 & 4 & 0 & 52 & 16 & & 3 & & & & & $6 c$ & 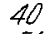 & 1. & 29 \\
\hline <゙ & 0 & 8 & $\pi$ & 92 & 96 & 44 & 5 & 96. & 10 & & 86 & & & & & 2 & & & 76 \\
\hline $1+$ & 88 & 88 & 100 & 100 & 100 & 84 & 80 & 92 & 10 & . & 52 & 4 & 0 & & & 11 & 36 & 6 & 25 \\
\hline 7 & I & 0 & 60 & 80 & 100 & 0 & 144 & 72 & 10 & & 92 & 100 & & & & 18 & & & $\gamma$ \\
\hline & 8 & 36 & 60 & 84 & 100 & 16 & 3. & 76 & 7 & & 8 & 88 & & & & & & & \\
\hline 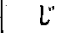 & 8 & g. & 10 & 100 & 10 & 32 & & 9 & 8 & & & 7 & & & & & & 75 & \\
\hline 7 & 0 & 80 & 100 & 100 & 7 & 60 & 8 & S & g. & 36 & 100 & 100 & & & & 44 & 4 & 4 & 40 \\
\hline 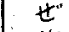 & 40 & 20 & 72 & 88 & 100 & 12 & & & 80 & 16 & 24 & 84 & & 2 & 16 & 40 & & 24 & \\
\hline 迄 & 1 & 72 & 80 & 96 & 100 & 20 & 44 & 60 & 10 & & 64 & $a$ & & & & 3 & & & 12 \\
\hline to & 27 & 76 & 10 & 92 & 10 & 72 & 6 & 9 & & & 0 & & & & & & 44 & & \\
\hline & I & 2 & A & 40 & 04 & 8 & 28 & 24 & 84 & 1 & 40 & 4 & & 0 & 4 & 28 & & & 107 \\
\hline$y$ & 3 & 60 & 92 & 96 & 100 & 28 & 80 & 44 & 76 & 40 & 64 & 68 & 18 & 0 & 20 & 8 & 24 & 12 & 12 \\
\hline & 7 & 88 & 80 & 96 & 100 & 88 & 72 & 92 & & 68 & 96 & 100 & 9 & & 20 & 72 & 44 & & 16 \\
\hline 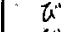 & 68 & 72 & 64 & 84 & 100 & 68 & 6 & 76 & 8 & & & & & & 4 & & & & 0 \\
\hline & 0 & 40 & 92 & 100 & & 28 & 84 & & 9 & & & & & & & & & & \\
\hline & 44 & 64 & 40 & 92 & 100 & 72 & 32 & 92 & 92 & 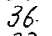 & 16 & 80 & & 8 & 17 & 64 & 64 & 32 & .0 \\
\hline ほ & 4 & 8 & 16 & 80 & 92 & 0 & 12 & 84 & 88 & 32 & 32 & 96 & 4 & 4 & 64 & 88 & 76 & 4 & 16 \\
\hline th & & a & 96 & 100 & 100 & 20 & 100 & 100 & 100 & 88 & 10 & 9 & 9 & & & 72 & 36 & 0 & \\
\hline$や$ & 56 & 100 & n & 100 & 100 & 92 & 9 & 100 & 100 & 2 & 10 & 10 & & & & & 96 & & \\
\hline (7) & 64 & 100 & 100 & 100 & 100 & 88 & 100 & 100 & 100 & 7 & 84 & 10 & & & 8 & 88 & 76 & $U$ & 170 \\
\hline & 64 & 9 & 96 & 96 & 100 & 76 & 1100 & 100 & 00 & & 96 & 10 & & 10 & 4 & & 56 & & 54 \\
\hline
\end{tabular}




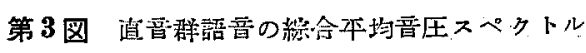

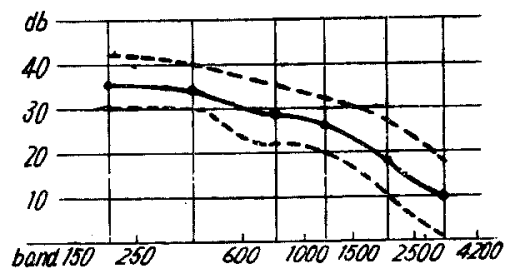

第4図 jc の語曋スペクトル (stevens, Fgan and Miller による) band 币の相起 による測定值の比蹬 4cFilter, Mel bandFilter

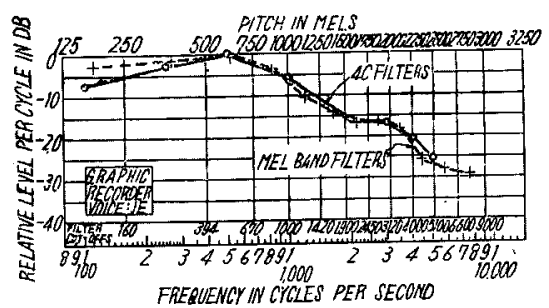

語音のスペクトルは第 2 及び第 3 表の明瞭度と比較し てないがこれれついての検討は総括の項で述べる，各 語音についてのスペクトルを則定しているが紙面を要す るため総括の項で表示し，その中で代表的な数例につい て図示する。

6) band 内成分のみを除去し band 外の 語音成分を聴取させる方法による明瞭度

a）測定装監及び測定法

第 2 図の装置を使用したが装置の接続が異なるだけで 第 5 図の如くである・測定法も（2）と同様であるが， filter の組合せが異つている・filter の組合せは第 4 表 で, H 而び L は high 及び low pass filter で数字 は KC 単位である・これらの組合せで例えば H4.0-L
第 5 图 band 外語晋成分のみを聴取ささる藵置

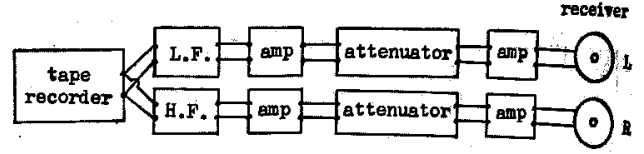

3.0 では左耳は $3000 \mathrm{cps}$ 以下の語音成分のみが鯂取さ れ，右耳は $4000 \mathrm{cps}$ 以上の語音成分か゚聴取されること になる・両耳より与えた 語音は脳中枢で合成されるか

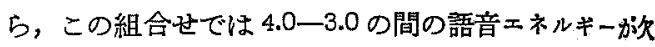
除することになる・語音を或周波数を限界として $\mathrm{H}$. 及び L. filter で切断して別々に画耳に与劣ると完全に 脳中枢で合成されて filter を㧴入しない場合の明膫度 と等しいものが得られることは Bocca によつて発見さ れた事実であるが，服部む追試によつてこれを茨めてい る・著者はこの事実を語音明瞭度と語音構造の閣保它研 究する目的に利用した・

第 4 表 H 及び L. filter の組合せを示す

\begin{tabular}{|c|c|c|c|}
\hline H. L. & H. L. & H. L. & H. L. \\
\hline $4.0-3.0$ & \multirow{5}{*}{$2.5-1.5$} & \multirow{5}{*}{$1.5-0.5$} & \multirow{5}{*}{$1.0-0.35$} \\
\hline $4.0-2.1$ & & & \\
\hline $4.0-1.5$ & & & \\
\hline $4.0-1.0$ & & & \\
\hline $4.0-0.5$ & & & \\
\hline
\end{tabular}

b) 測 定 成 續

両耳の聴力が正常でオージオグラムが Odb 以上であ る被検者のみ 23 名を選抜して a）の組合せで行つた直 音群の平均明膫度成頻は第 5 表である・明䀨度は 4,0 $0.5 \mathrm{KC}$ の広いband が矢損した場合を除いて明榺度仕 著しく良讬で，侵され難いのは第 2 及び第 3 表の成綪 比較して興味梁い. その検討は後に述べる・

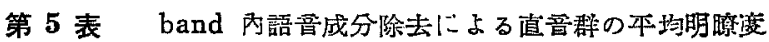

\begin{tabular}{c|c|c|c|c|c|c|c|c}
\hline 欠 摃 band & $4.0-3.0$ & $4.0-2.1$ & $4.0-1.5$ & $4.0-1.0$ & $4.0-0.5$ & $2.5-1.5$ & $1.5-0.5$ & $1.0-0.35$ \\
明 暸庰 \% & 95.8 & 95.6 & 92.1 & 82.0 & 46.6 & 95.1 & 92.0 & 92.2
\end{tabular}

\section{7. 総括並に考按}

語音を filter で分割し種々なる音域に周波数歪を起 させこれに対する正常耳の明瞭度を測定し，更に同じ手 段によつて語音の音響スペタトルを測定，両者の成結よ り語音の音曏構造と語音了解との関係について基碟的知 識を求めた・
本研究で検查語音を直音群に限つた理由は海老原 (昭 31 年）の報告によれば，直音群も拗音群もとの僜做 椂が同じであると云ら事奏に基いている・な㨁音僻 拗音群を加えた語音表にて前述の如き複雑な測定を行え ば，被険者の精神的疲労が著しくなるため反って模臹 樍を低下させる危険があることが予備実験で判明したこ 
とにむよっている。

直音皏住して band pass によつて得られた明瞭度 成辕の第 2 表によれば band $4.2 〜 2.5 \mathrm{KC}$ と $3.0 \sim 2.5$ KC の明膫度は $34.8 \%$ であり殆んぞ 差がない。これよ り語音は 100 10000 cps の周波数成分上り檏成されて いるとは云完 $3000 \mathrm{cps}$ 以上の周波数成分は，明瞭度に 対して殆んど重要でないと云える・3.0〜2.5KCの band を拡大して 3.0〜-1.5KC にすると明瞭度は急に 2 倍に 增暆するのが認められる・これより $2.5 〜 1.5 \mathrm{KC}$ の成分 音が丢要であることが分る・逆に 3.0〜 1.5KC と 2.5〜

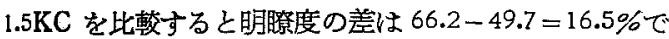
あり，この差に相当する $3.0 〜 1.5 \mathrm{KC}$ の成分む明瞙度に かなり関你している・2.1〜1.5KC より $3.0 〜 1.0 \mathrm{KC}$ K 抵大すると $66.2 \%$ より $14.8 \%$ に増加して $81 \%$ になり， この明膫度では会話あるいは交章の了解は $95 \%$ 上上殆 んと完全になる・故に 1.5〜1.0KC の成分音は非常に重 亚てある・これと同様に $2.1 〜 1.5 \mathrm{KC}$ 上り $2.1 \sim 1.0 \mathrm{KC}$ 飞拉大寸ると $49 \%$ - $63.4 \%$ 即ち $14.4 \%$ の増加となる。

この所見より 1.5〜1.0KC の堌加は約 $15 \%$ の明膫度増 加に相当することが認められる。

$3.0 \sim 1.0 \mathrm{KC}$ より $3.0-0.6 \mathrm{KC}$ の搥大は 81 より $88.4 \%$ に変化し 7.4\% の明瞭度増加にとざまり $3.0 \sim 0.25 \mathrm{KC}$ の 拉大は $88.4 \%$ より $97.1 \%$ 即ち $8.7 \%$ の増加で $1.0 \mathrm{KC}$ 以 下の band の拨大㤝，2.5 1.0KC の抾大に比して明膫 度の增加は半分に過ぎなくなつている・更に上限が 4.0 ， $3.0,2.1,1.50,1.0,0.7,0.5 \mathrm{KC}$ いずれに対しても 0.25 〜0.15KC の拹大は殆えど 明瞭度の増加を起していな い. 上上を要約すると語音了解に 重要な音域は 3000〜 $1000 \mathrm{cps} て ゙ ，$ 次が 1000 250cps であることが分る・下 限 $0.25 \mathrm{KC}$ に䴔して明瞭度が急に減少し始める上限を 求めると $1.5 \mathrm{KC}$ である・1.5 0.25KC では明膫度 $80 \%$ であるが，1.0 0.25 では 59.7\%に急減している・こ の点よりすれば日本語の予解に必要な 最小限の 音域は 1500 250cps と云える・これは英語の同音域が 2000 〜500cps と云われている所見とかなり差がある.

以上の所見の外に奇妙な現象が弪められる・明膫度が band の桩大と共増加するのは当然之考えられるが， 逆減少する現象が認められる・それは上限を $1.5 \mathrm{KC}$ とする band 拡大に文すする明瞭度の变化である・1.5〜 $0.25 \mathrm{KC}$ までは明膫度が堌加するが $1.5 〜 0.15 \mathrm{KC}$ 即る 0.25 0.15KC が加わると明瞭度は 80\% より $65.6 \%$ K 急減している.この傾向は上限が $1.0 \mathrm{KC}$ 及び $0.7 \mathrm{KC}$ である場合の band 拡大にも想められる・1.5〜0.25KC
の成分音に刘して 0.2〜 0.15KC の成分音が妨害的に作 用している・これと同様の所見が French and Steinberg の研究傝められ mter band masking と呼ば れている・詳細はデーターは述べられてないが，著者の データーよりすれば interband masking は上限 1.5 $\mathrm{KC}$ に著明で 1.0 及び $0.7 \mathrm{KC}$ に著明でないことより 0.25 0.15KCによる masking は 1.5 1.0KC $の$ band に作用していると考完られる・第3図の語音スペクト ルよりしても 0.25〜0.15KC の音圧忙最大であるから interband masking の可能性は畩書される・故比 0.25 ー0.15の成分は除去され秝ばならない.この見解よりす れば補聴器の出力特性は 250cps 以下で急激に下降す るものが望ましいことになる・

第 2 表の成績より第 6 表の如き 5000 cps に近い band 毎の平均明瞭度が得られる・これより $1.5 \sim 1.0 \mathrm{KC}$ が 最良の明膫度を有し， $2.1 \sim 1.5 \mathrm{KC}$ と $1.0 \sim 0.6 \mathrm{KC}$ の band が次いで良好な明瞭度を有していることが分る。 これ恃第 2 表の上限 $4.2 \mathrm{KC}$ 文び $3.0 \mathrm{KC}$ の band 扰大 之明瞭度の関係にも明瞭に認められる。

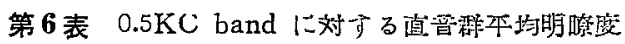

band $3.0-2.5|2.1-1.51 .5-1.0| 1.0-0.6^{\prime} 0.7-0.40 .5-0.25$

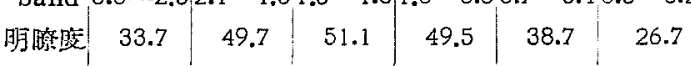

語音成分は相互に助け合つて明膫度を增加する傾向が 大であるが，ある band 成分は他の band 成分に妨害 的に作用することも認められたから，狭いband に 対する明瞭度を求めることは意味が少ない，第6表の band が2つ以上合成された時の明瞭度はいがなるか， こ杜既に第2 表にて知られるところであるが，デー ターを整理してみると次の如くになる・第6表の卷い band 毎の明瞭度を加算すると 3.0 より $0.15 \mathrm{KC}$ までよ゙ 合計明瞭度 $249 \%$ になる・3.0〜0.15KC の実際の明瞭 度は $97.4 \%$ である・分割 band が広くなると明瞭度の 単なる加算量性次第に減少寸る・3.0〜 1.5KC の明膫度 は66.2\%であり，1.5〜0.15KCは65.6\%であるから， 画者の合計明䦽度は $131.8 \%$ となる. $500 \mathrm{cps}$ banb の合 計明膫度で $249 \%$ は $1500 \mathrm{cps}$ band の合計明膫度 131.8 \%に減少する・しかるに武山の测定では 375 750 cps, 750 1500cps, 1500 3000cps 及び 3000 6000cps の band 毎の明膫度加算が $84.6 \%$ よなつている・第 2 表の 著考のデーター一で換算すると 400〜 700cps は 38.7\%， $750 \sim 1500 \mathrm{cps}$ は66.8\%，1500 3000cps は 66.2\%， 
$3000 \mathrm{cps}$ 以上は省略するとしては合計明瞅度 $171.7 \%$ に ならなければならない，著者と同様な所見は Fletcher 以㷋 French and steinberg, Stevens, Egan and Miller, Pollack のデーターに共通して認められる・例 えば Fletcher では第6図の如く low と high pass filter で $1550 \mathrm{cps}$ を境として高低の 音域に分割して得 られる夫ネの音域は65\%で，その合計明膫度は130\% となる・この值は前記の著省の $1500 \mathrm{cps}$ で分割した band の明瞙度が高音域で66.2\%，低音域で $65.6 \%$ と わよく一致していると共に，合計明瞭度 $131.8 \%$ とは更 によく一致している.

第6 図 Effect upon the Articulation and Energy of Sqeech of Eliminating Certain Freouency Reoions. after Fletcher

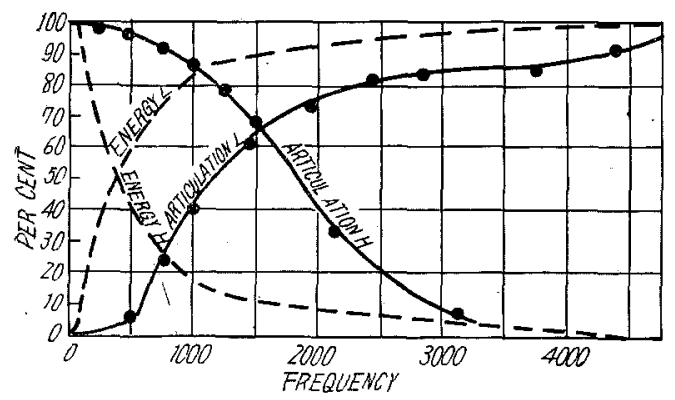

この現象は語音構造が語音了解に対して極めて適切な もので, 分割に対して比例的に明瞭度が娍少しない構造 になつている・換言すれば語音成分間にはかなり強い独 立性があり，狭い部分の成分音です語音の特徽を失うこ とが少ないと解釈される・

第3表は以上述べた第 2 表のデーターを詳細に分析す るに役立つ・例えば「あ」の明瞭度は表を左より右に眺 めると $3.0 \sim 1.0 \mathrm{KC}$ で 100\%となるが，2.1〜0.6KCで む 100\%であり，1.0〜0.6KCでも 96\%であり，明膫度 は極めて良好である・このような特徽を分り易くするた め第 3 表より直竟洋の一部を分類したの方第7表であ 万・表の右端の $90 \%$ 明は $90 \%$ 上上の明膫度が得られる 最む狭い band 老萴入している行で，80％明も同様な 行である・

母韻は「お」以外はどの band でもかなりの明睹度

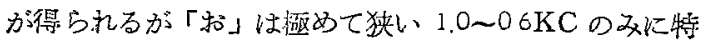

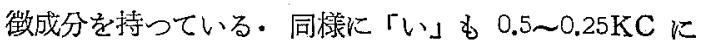
特致を有しているが，隣の 0.25〜0.15KC の成分で著し

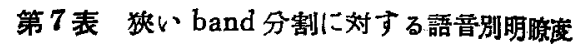

\begin{tabular}{|c|c|c|c|c|c|c|c|c|}
\hline 意 & & & & $1,0-2$ & par on & $a_{3}-a_{x}$ & 0.97 & \\
\hline b) & 36 & 64 & 92 & 96 & 80 & 12 & 4 & 2610 \\
\hline$n$ & 48 & 48 & 28 & 76 & 64 & 92 & 58 & $2.5-0.24$ \\
\hline 2 & 28 & 48 & 68 & 44 & 36 & 28 & 79 & $\sqrt{65}$ \\
\hline $\bar{\lambda}$ & 60 & 88 & 48 & 72 & 72 & 63 & 54 & $|30-10| 2$ \\
\hline ま & 12 & 8 & 72 & 96 & 72 & 20 & 20 & $140-6$ \\
\hline$z$ & 88 & 68 & 64 & 60 & 52 & 56 & 54 & $150,-1$ \\
\hline It & 88 & 52 & 24 & 16 & 28 & 16 & 29 & $3.0-45$ \\
\hline l" & 88 & 32 & 32 & 40 & 76 & 75 & 45 & $30-7$ \\
\hline げ & 88 & 84 & 44 & 40 & 56 & 64 & 25 & $30-1,0$ \\
\hline y & 80 & 0 & 16 & 44 & 60 & 80 & 79 & $3.0-1.53$ \\
\hline$\leq$ & 0 & 28 & 88 & 100 & 36 & 44 & 62 & $1.0-0.61 .5$ \\
\hline 2 & 8 & 24 & 100 & 96 & 96 & 16 & 16 & $a 7-04$ \\
\hline ま & 16 & 36 & 60 & 100 & 12 & 0 & 4 & $10-0.6$ \\
\hline 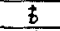 & 4 & 4 & 52 & 100 & 92 & 23 & 20 & $10.7-2$ \\
\hline 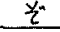 & 4 & 20 & 24 & 60 & 32 & 16 & 12 & $21-a 2030-10$ \\
\hline <" & 0 & 44 & 48 & 40 & 20 & 20 & 25 & $30-0.61 .0002$ \\
\hline 1* & 44 & 72 & 36 & 28 & 12 & 32 & 16 & $30.0-0.15-0.20$ \\
\hline$\lambda^{0}$ & 8 & 56 & 16 & 12 & 20. & 4 & 16 & $42-0$ a 3.0 \\
\hline Si & 8 & 28 & 76 & 32 & 0 & 32 & 20 & $10-0.4$ \\
\hline$\ngtr$ & 56 & 92 & 24 & 76 & 92 & 8 & 29 & $a 7-a 4$ \\
\hline 功 & 64 & 88 & 76 & 32 & 28 & 80 & 70 & $15-02$ \\
\hline 5 & 64 & 76 & 68 & 80 & 84 & 52 & 54 & $1.0008607-0$ \\
\hline $12^{\circ}$ & 4 & 4 & 36 & 4 & 12 & 16 & 0 & $\angle 50 \%$ \\
\hline 12 & 0 & 0 & 32 & 44 & 24 & 0 & 4 & $<65 \%$ \\
\hline
\end{tabular}

い masking を受けている・「ら」「え」は90\%以上の 明瞭度を得るには夫ょ $3.0 〜 0.25 \mathrm{KC}$ 及び 3.0〜1.0KC のかなりの広い band を必要とする・「え」は 2.1 1.5 KC 及び 0.7 0.4KC の2つの band K特徽成分壳有 している・この所見は「じ」「り」「や」「」「よ」に最 も明白に認められる・3.0〜2.5KC の高音域 band に著 しい特徽成分を含んでいるるのに「て」「け」「し」「け」 「り」がある・90\%上上の明膫度を保有しているのは 1.0 あるいは $1.5 \mathrm{KC}$ 以上の高音成分であることか゚分る。 これらと反対に $1.0 \mathrm{KC}$ 以下の成分が90\%以上の明凌 度を有する語意には「く」「こ」「ぬ」「」等がある。 band 分割で著しく明瞭度が失われる語音は「军」「く 「ベ」「ペ」「ぱ」「ぱ」等がある・これらの明膫度 $90 \%$ 它得るには広い band を必要とする。「ペ」は 4.2 0.25 KC で最も広い band を必要とし「ぐ」「べ」3.0 $0.6 \mathrm{KC}$ でかなり広い. 殊に band 分割によって著能 明瞭度が失かれるが，広い band をむつてして子明胯 度が50\%あるいは65\%以上にならない語音に䚾」 「ぱ」がある・このよらな語音は狩徽成分が不明瞭な

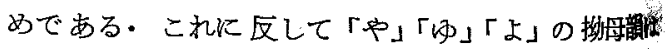
band 分割に抵抗性が大で明瞭度が非常に大である.以 上の如く band に分割ずることによつて明暸度が絆 れ易い語音と失われ難い語音とがあるが，全体としで 第6 表の平均值で認められる如く分割に耐える語音か W. 
band と明盼度の関係は語音の特徽成分が band 内に らるかどが奬っていることが分つたから，これら つ特徽成分の音圧を测定してみる必要がある・直音群㮩 つて band 内の 音圧の平均值を示しているのが第 3 园である band 内の音圧の測定值は band 内の成分中 㷉大のものを代表しているに過ぎない. 故に band 幅 が狭い程語音の音響スペクトルは詳細に正磪に湘定され ることになるが, Stevens, Egan and Miller の研究 では 250cps band 幅で測定して得られる語音スペタト ルむ500cps あるいは音域によつてはそれ以上の幅で測 定して得られる語音スペタトルと相違が少ないことが第 1 図に示されている・良つて著者の湘定に使用したband 湢も等容される・且つ彼等の得た語音スペクトルと著者 つそれはよく一致している・第3図では band の音圧 は band の中間の周波数に軸に記入している・例えば 2.5 1:0KC の音仕測定值は 2000 cps の軸上にとつてい る・実線で直音群の平均值でこれの上下に描かれている 割線伍 語音別に測定して 得られた最大值と最小值であ 子.

語音成分の音圧の相違によつて語音の音響的区別がつ けられると考えるならば, 平均檤, 最大値及び最小值音 代スペクトルのいつろれも語音では低音 band 音圧が最 も大である所見は前記の明瞭度の所見と逆であり期待に 反する・ band 毎の平均明瞭度は第6 表の如く 1.5〜 1.0 $\mathrm{KC}$ を中心として最大であるから，1.5〜1.0KC の音纴 が灵大でなければならないが，この所見は第3図に認め ら氿ない. 更に立場を变えて 成分音圧の語音別の 差違 を目標とすると，最大值と最小值の間にある 变動幅は 1.2 2.5KC 及び 2.5〜1.5KC が約 $17 \mathrm{db}$ で最も広いが, 言大明膫度を示す $1.5 \sim 1.0 \mathrm{KC}$ の音圧の変動幅は約 12 lbで比較的狭いのが其待に反する・しかしこの変動幅 为て各語音の音生は区別がつくかどうか詳しく調べて見 万必要がある・既に述べた第 7 表で狭い band に著明 垨徵成分を有する語音を選び第 8 表の語音別 band 音 ，Eとを照合すれば，「ま」の最大明膫度の band は 1.0 -0.6KC, 次で 1.5 1.0KCであり，これに対して band 压は 1.0 0.6 KC 及び 1.5〜1.0KC で, 夫ヶ6及び db（剆定では 60db を基準とした）である・これを図 可る第6図の如くになる・即ち語音間の音王の偏差 “殿大值と最小值の割線間) から見れば「ま」は最大明 留 band と一致して, band 音圧は最大の判差を示 てている・同様に「て」を图示すればその最大明瞭の ind 3.0 2.5KC に一致して, band 音仕も最大偏差を
示している・「护」の最大明瞭度の band 1.0〜0.6 KC で は逆に音圧が低くなつているが，偏差の点から見れば 「て」とは逆方向の最大偏差を示しているから語音の区 別に役立つことになると考えられる・

第 8 表 直量群語䆨の band 害压 $(60 \mathrm{bd}$ をOdbをす尚)

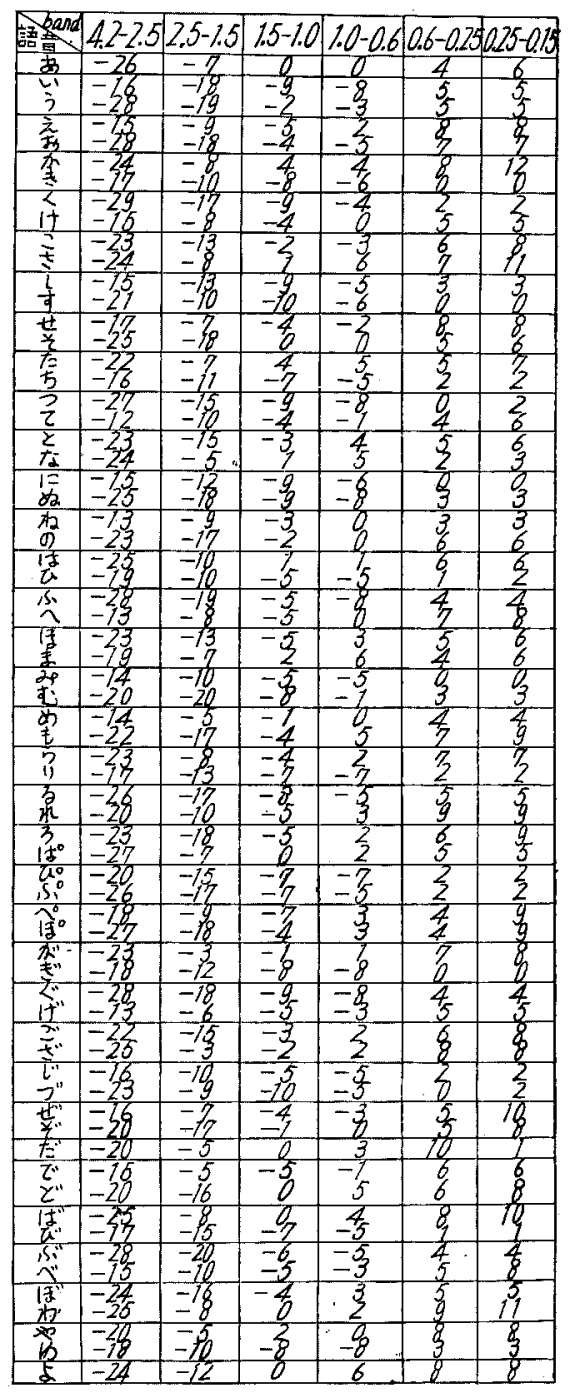

「し」は band 分割で著明に明睹度が悪くなり広い band を必要とする語音に属するが，3.0〜2.5KC と 2.1 〜1.5KC では比較的明䀢度が良くなつている・これと 一致して band 音圧も偏差を示しているが，その band 音圧間には 4.2〜0.6 KCに招いて比較的差ぶ少ない点が 


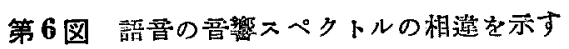
上下の割線の間での偏差でる

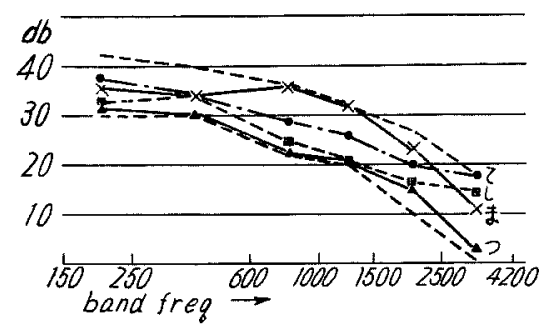

認められる・これが明瞭度の良好でない原因と考光られ る.「つ」の band 明睹度は第 3 表より $1.5 \sim 1.0 \mathrm{KC}$ は $56 \%, 1.5 \sim 0.6 \mathrm{KC}$ は $32 \% と$ interband masking $K$ よつて低下しているが，1.5〜0.25KC に㹡がつたざけで 明瞭度は $96 \%$ に急に增加する・故に 0.6〜0.25KC の band が明瞭度に特に必要であることが分る・更に 1.0 〜 $0.6 \mathrm{KC}$ では明暸度 0\%. 1.0〜0.25KC では $8 \%$ と 1.5 〜1.0KC の banb を欠ぐと急激に明膫度が悪くなつて いる・故に「つ」には 1.5〜1.0KC 及び $0.5 \sim 0.25 \mathrm{KC}$ が物に必要な band であることが分る・この所見より band 音纴を眺めると 1.5〜1.0KC では；音圧は他の語 音のそれよりも最も低いししかし偏差から云えば最大で ある・次に重要な $0.6 \sim 0.25 \mathrm{KC}$ の音纴む同棦の傾向を 示している・な拈「つ」は 4.2〜2.5KC の音生は低い。 これに比例して明瞭度も $36 \%(3.0 \sim 2.5 \mathrm{KC}$ で 28\%) で低いが，8.0〜1.5KC では急に84\%となる.これに対 して 2.5〜1.5KC の音圧は高くなつていない. 2.0〜 1.0 $\mathrm{KC}$ に広くなると明瞭度 $92 \%$ と堌加し，更に 1.0 〜.6 $\mathrm{KC}$ が加わり 3.0〜0.6 KC となると 88\%に減少する。 これは前記の $1.5 \sim 1.0 \mathrm{KC}$ と $1.5 \sim 0.6 \mathrm{KC}$ で interband mashing が起つたと同一現象である・故に 3.0〜0.25 KC になると明瞭度 100\%となる・「つ」は明膫度が大 なる語音であるが，これを全体的な成分音王からみれば 語音中最も低いものに属する・しかるに明瞭度よりみれ ば「つ」では 2 つ重要成分を有し，低音の成分は 0.6 〜0.25KC にあり，高音の成分は 1.5〜1.CKC にある・ 更に $1.0 \mathrm{KC}$ を境として高低に切断したband の明暸度 より寸れば， $0.6 〜 0.2 .5 \mathrm{KC}$ の成分よりむ $1.5 \sim 1.0 \mathrm{KC}$ の成分が最も重要である・以上の如く語音スぺクトルと 明膫度即ち第 3 表と第8 8 表を比較すれば，語音の音圧成 分よりも語音の特徽を有する周波数成分が明瞭度に重要 であることが認められる・

語音了解に必要な音域は上上の測定データーの分析に
よつて求められたがこれらの知見を補足する意味て咅 音域の一部の band 成分のみを除去した場合に明摬度 はいかに变化するか測定する必要がある・第 5 図の漖置 によつて得られた成績は第 5 表である・これを第 3 表之 比較寸れば，例えば 4.0〜1.0KC band pass.で明膫 度 $81 \%$ であるから，この逆の band choke では明璄 度 19\%が期待されるが，予斯に反して $82 \%$ で明师度の 低下は非常に少ない. band choke の幅を拡大して 4.0 〜0.5KC にすると，明暸度は急激に $46.6 \%$ に低下して いるのが認められる・他の音域では band choka が 狭い場合は殆えど明膫度の妨げとなつていない，band choke の成續では 4.0〜1.0KC より 4.0〜0.5KCへの 变化が著しく明䐲度に 影響していることよりすれば， 1.0〜0.5KC の band が語音の最も重要な成分を゙含れで いると云える・しかし既に述べた第6表よりすれ住 1.0 $\sim 0.6 \mathrm{KC} \rho$ band pass $の$ 明瞭度は良好でするが, 2.1 〜1.5KC 文び 1.5〜1.0KC の明瞭度と殆んど同じ位で ある・この明瞭度の相違は聴取方法の相違か、起るとは 考党られない，即ら band choke で恃両耳聴を使用し なければならない点から band pass の聴取法る一猎 で行觉るに拘らず両耳聴で行い，band choke の聴取洗 と条件を合せるよ5に配慮しているからである・band pass では同じ band が両耳に聴取されるが, band choke ではその幅が広いと一耳の語音ェネルギーは非常 に少く, 両耳樒でも band pass より語音の loud ness は小であるに拘らず明瞭度はよいここれは band choke 两端の語音成分がよの補足し合う作用が強いと考充られ る.特に 1.0 0.5 の band 成分は他の band 成分已補 足し合つて明膫度を高める作用があると考皇られる・第 2 表と第 5 姜を比較すれば band pass $4.2 \sim 1.0 \mathrm{KC} の$ 明瞭度 $84 \%$ と band choke $4.0 \sim 1.0 \mathrm{KC}$ の明膫度 $82 \%$ であることから，晎なる話者 2 名の語音をこの周波数域 で分割して同一通話線に通じ，受信側で flter て再い 分離して別たの受話器に再生することによって同时飞2 種の異なる通信が行えるこ上が分る。

語音の音代スペリトルの共通所見は前記の如く高暗 程成分音圧が低下している・この所見は耳の感度周没 特性と比較する必要がある・本矿究のデーターは㥅話器 より得られたものであるから，受話器で得られた正赏耳 の感度周波数特性を刘象にとらねぱならない：これに相 当寸るるのは第 7 図の感度曲線 b である (Sivian and White 及び Nunson に扰る)・b曲線は耳の感度加 1000〜4000cps に亘つて最犬となり，200cps のそれ 
第7图 正常耳の感店周波数特性を示寸

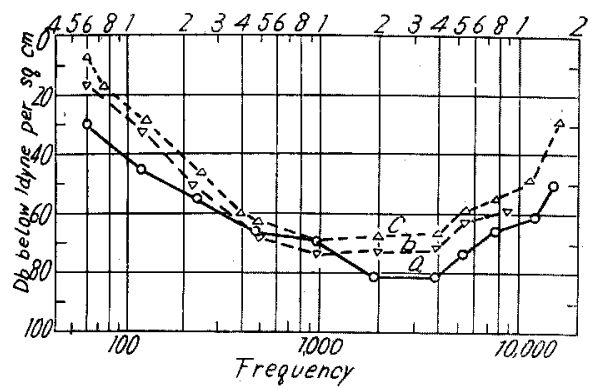

Fig. Threshold sensitivity of the human ear, as measured under three conditions. For curve a binaural stimulation, free-field; average of results for 10 sublects, Eor curve b : binaural stimulation, closed.ear procedure; results for 22 subjects. For curve $\mathrm{c}$ : uniaural stimulation, closed-ear procedure; results for tne 22 ears of 10 subjects, The data were obtained by $W$. A. Munson, and most of them have been reported by Sivian and White.

比して約 $25 \mathrm{db}$ 良好となつている・こ礼㖊して簤 3 図 の語音スペクトルでは 150〜250eps の音圧に対して 2500 4000cps の音纴は 26db 低下している所見より， 語音音迌スペタトルと耳の感度は補足し合う関俰が認め られる・即ち音圧の低い語音の高音成分を低音成分の強 さまで耳が増幅していると云える・この関係よりして耳 の音響機能そのものも単に楽音あるいはその他の音響を 聴くためのむのでなく，特俉音を受領しこれを了解す る通信の目的にのみ合致するよう作られていると考えら れる。

\section{8. 結 諭}

テープに録音した語音を 再生する途中に high 及び Jow pass filter の種くなる組合せを㧴入して再生語音 を種くなる band に切断し，これに対する正常耳の明 䐀度を測定し語音の音響構造と耳の機能の関係を研究し て次の結論を得た。

1) band pass の融が狭くなるにつれて 語音の明瞭度 が低下するがその低下の割合は反つて減少する・換言寸 れば語音は狭いband に分割されてもその特徴を失う ことが少ない。

2）語音の多〈は約 $500 \mathrm{cps}$ 幅の狭いband 成分だけ でも充分な 明瞭度を保持するが，小数の語音（ぽでぱ 等）には 4.2 0.15KC の音域でも充分な明膫度を有し ないるのがある。
3）語音を band 成分に分けて得られる明瞭度よりす れば 1.5〜1.0KC の成分が重要で 2.1〜1.5KC 及び 1.0 〜 $0.6 \mathrm{KC}$ 。前者と殆えど同じくらい重要である.

4）直音群語音の平均明瞭度 $80 \%$ が得られる 音域は 1.5 0.25KC でありこの音域が最も電要であるから日本 語の語音域と名付けてよいであうう・これを英語の語音 域 $2.0 \sim 0.5 \mathrm{KC}$ に比して約 $500 \mathrm{cps}$ の相違がある・故に 補聴器の出力周波数特性は 1.5 0.25KC に括いて 良好 でなければならない。

5） $0.25 \sim 0.15 \mathrm{KC}$ の語音成分は他の成分に比して音圧 が大であるため反つて他の成分を mask ᄂ明瞭度を低 下させる作用がある・故俌聴器の出力周波数特性は $250 \mathrm{cps}$ 以下が四断されたものが望をれる。

6) 語音は 1 つの band 成分の及が除去された場合似 は明膫度の 低下は少ない４.0 0.5 KC の広い band elimination でも明瞭度は 46.6\%に止まつている・同幅 の band pass では多くの語音が 90〜100\% の明蹽度を 保持している所見と全く反対沈ならないここれり狭 いband elimination では band 両端にある成分音の 相互に補足し合万作用が大で明瞭度は $80 \%$ 以上になる。

7）語音の音仕スペクトルは低音域程高く高音域程低 下する・このスペクトルの形は語音によつて異るが高音 域では $17 \mathrm{db}$ 以内で低音域では10乃至 $12 \mathrm{db}$ に止まつ ている.

8）語音は音圧スペタトルの相違よりも特徵成分音の 周波数によつて弁別される傾向が大である。

9）語音スペタトルと耳の感度周波数特性の形状を比 較すれば耳の感度は 1000 cps 以上の高音域が高くこの ため音圧の小なる語音の高音成分を補足する所見が認め られる・これより耳の音響構造は語音を德取する目的に のみ合致していると云える。

\section{文献}

1) Fletcher, H.: Speech and Hearing 1929. 2) 落

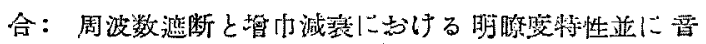

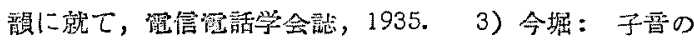

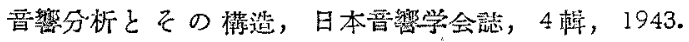

4) Egan, J.P. and Wiener F.M.: On the intelligibility of bands of speech in noise, J. Acous, soc Am. 18, 435 1946. 5) French, N.R. and Steinberg, J.C.: Factors governing the intelligibility of speech sounds J. Acous. Soc. Am. 19,90. 1947. 6) Stevens, S.S., Egan J.P. and Miller, G.A.: Method of measuring speech spectra, J. Acous. Soc. Am. 
19, 771, 1947, 7) Pollack, I.: Effects of high pass and low pass filtering on the intelligibility of speech in noise, J. Acous. Soc Am 20, 259, 1948. 8) Breakey, M.S. and Davis, H.: Comparison, of thresholds for speech, Laryngoscope 59, 236, 1949. 9) Wiener, N.: Speech Language and Learning, J. Acous. Soc. Am. 23, 696, 1950.1 10) Fletcher H.: A method of calculating hearing loss for speech from an audiogram J. Acous. Soc. Am. 32, 1, 1950. 11) Potter, R.K. and Steinberg, J.C.: Toward the speec fication of speech J. Acons. Soe. Am. 22, 807, 1950. 12) Martin, D.W.: uniform speech-peak clipping in a uniform signal-tonoise spectrum ratis, J. Acous. Soc. Am. 22, 614, 1950. 13) Hawkins, J.E, Jr. and Stevens. S.S.: The masking of pure tones ans spssch by white noise, J. Acons. Soc. Am. 22, 6. 1950.14 ) Peterson, E.: Frequency detection and speech formants. J. Acous. Soc. Am. 23, 668, 1951. 15) Carhart, $R_{\text {.: }}$ Speech audiometry in clinical evaluation
Acta Ntolaryng. 41, 18, 1952 .

16) Bocca, E,

Binaural hearing: another approack, Acta Oto

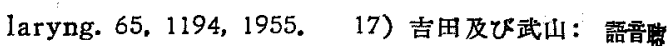
力検香試験用語の作成，耳莮咽喉科，26，501，招 29 。

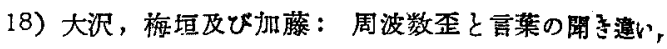

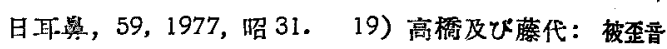

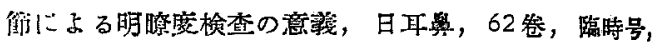

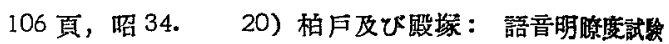

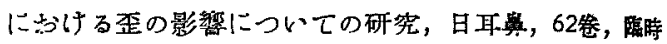

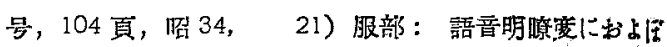

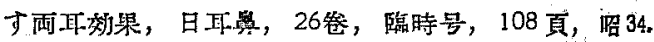
22）海老原：Confusion matrix に上る日本誌㯖力權

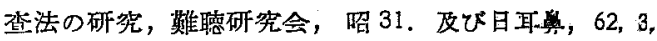
17, 沿 34 .

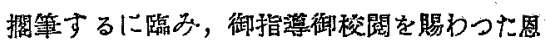
師山崎教授並びに東京医科菡科大学恩地教授に 深謝します。

（原稿到嘻 $=$ 炤和 34.5.18 日一急載）

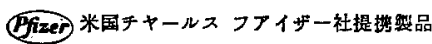 \\ 新発完!

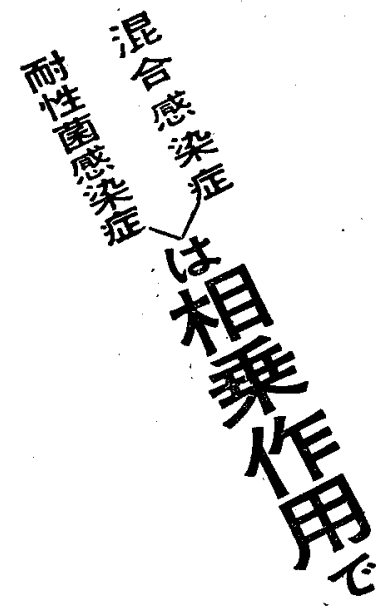 \\ 広範囲抗生物質 複合剤

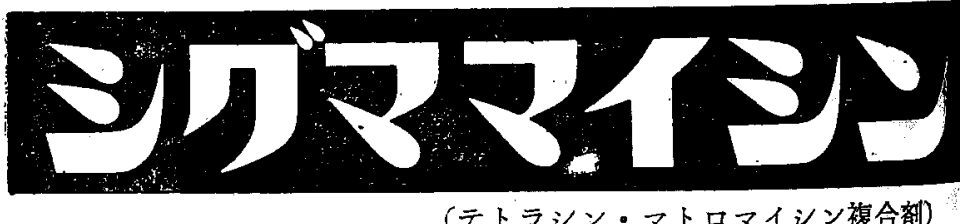 \\ 広範囲抗生物質複合剂として、世界的に賞用されておりますングママインンは 広範团抗生物質テトランン（テトラサイクリン塩基）に、耐性フドウ球菌にる 強い抗菌力を示すマトロマインシ“(燐酸オレアントマイシン)を、最あ合理的 に配合した新抗生物啠製剂で、最大の抗菌スペクトルを有し、相乗作用に㑈り 強力な治療効果を発揮します。

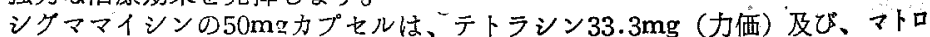 マインン $16.7 \mathrm{mg}$ (力洒) を含有し、シグママインン $250 \mathrm{mg}$ カプセルは、テトラ ンン $167 \mathrm{mg}$ (力価) 及び、マトロマインン $83 \mathrm{mg}$ (力価) を含有します。 \\ 特 镸 (1)相乗作用に上り抗菌力が著しく増強される。(2)耐性菌に対してす姁 力を発揮し、しかす耐性菌の発現が遅延する。(3)吸収が速加て、副作 用あ極めて少ない

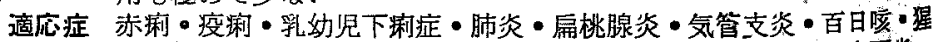

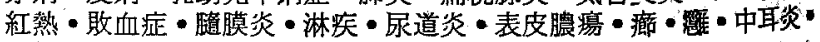 歯槽膿盃・発疹チフス \\ 包 装 $50 \mathrm{mg} 25$ カプセル入 $250 \mathrm{mg} 50$ カプセル入}

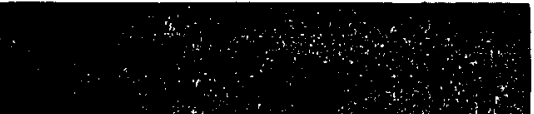

